\title{
Histamine neuronal system as a therapeutic target for the treatment of cognitive disorders
}

\author{
Patrizio Blandina ${ }^{\dagger 1}$, Leonardo Munari', Patrizia Giannoni ${ }^{2}$, Chiara Mariottini ${ }^{3}$ \\ \& Maria Beatrice Passani ${ }^{1}$ \\ 1Dipartimento di Farmacologia Preclinica e Clinica, Universitá di Firenze, Italy \\ 2New York University School of Medicine, NY, USA \\ ${ }^{3}$ The Mount Sinai School of Medicine, NY, USA \\ †Author for correspondence: Tel. .+39 0554271239 = Fax: +39055427 1280 = patrizio.blandina@unifi.it
}

Much has been learned over the past 20 years about the role of histamine as a neurotransmitter. This brief article attempts to evaluate the progress accomplished in this field, and discusses the therapeutic potential of the $\mathrm{H}_{3}$ receptor $\left(\mathrm{H}_{3} \mathrm{R}\right)$. All histaminergic neurons are localized in the tuberomammillary nucleus of the posterior hypothalamus and project to almost all regions of the CNS. Histamine exerts its effect via interaction with specific receptors $\left(H_{1} R, H_{2} R, H_{3} R\right.$ and $\left.H_{4} R\right)$. Antagonists of both $\mathrm{H}_{1} \mathrm{R}$ and $\mathrm{H}_{2} \mathrm{R}$ have been successful as blockbuster drugs for treating allergic conditions and gastric ulcers. $\mathrm{H}_{4} \mathrm{R}$ is still awaiting better functional characterization, but the $\mathrm{H}_{3} \mathrm{R}$ is an attractive target for potential therapies of CNS disorders. Indeed, considerable interest was raised by reports that pharmacological blockade of $\mathrm{H}_{3} \mathrm{Rs}$ exerted procognitive effects in a variety of animal tasks analyzing different types of memory. In addition, blockade of $\mathrm{H}_{3}$ Rs increased wakefulness and reduced bodyweight in animal models. Such findings hint at the potential use of $\mathrm{H}_{3} \mathrm{R}$ antagonists/inverse agonists for the treatment of Alzheimer's disease and other dementias, attention-deficit hyperactivity disorder, obesity and sleep disorders. As a result, an increasing number of $\mathrm{H}_{3} \mathrm{R}$ antagonists/inverse agonists progress through the clinic for the treatment of a variety of conditions, including attention-deficit hyperactivity disorder, cognitive disorders, narcolepsy and schizophrenia. Moreover, the use of $\mathrm{H}_{3} \mathrm{R}$ antagonists/inverse agonists that weaken traumatic memories may alleviate disorders such as post-traumatic stress syndrome, panic attacks, specific phobias and generalized anxiety. The use of $\mathrm{H}_{3} \mathrm{R}$ ligands for the treatment of neurodegenerative disorders is demonstrated in several studies, indicating a role of the histamine neurons and $\mathrm{H}_{3} \mathrm{Rs}$ in neuroprotection. Recently, direct evidence demonstrated that histaminergic neurons are organized into functionally distinct circuits, impinging on different brain regions, and displaying selective control mechanisms. This could imply independent functions of subsets of histaminergic neurons according to their respective origin and terminal projections. The possibility that $\mathrm{H}_{3} \mathrm{Rs}$ control only some of those functions implies that $\mathrm{H}_{3} \mathrm{R}$-directed therapies may achieve selective effects, with minimal side effects, and this may increase the interest regarding this class of drugs.

\section{Histamine is a neurotransmitter}

The first indication of the functional importance of histamine in the CNS can be traced back to the 1930s, when it was observed that centrally penetrating histamine $\mathrm{H}_{1}$ antagonists had marked sedative properties. However, no attention was given to histamine receptors as sites of action for these unwanted effects [1]. Indeed, the role of histamine as a neurotransmitter has been neglected for many years, in spite of early reports of its presence in the brain [2] and suggestions that this amine has central functions [3]. The delay in searching for a histaminergic neuronal system, in comparison to the exploration of other aminergic neurotransmitter systems, may rest on the methods available for their visualization.
The distribution of the catecholaminergic and serotonergic neurons in the brain became known using a fluorescent immunohistochemical analysis with o-phthalaldehyde as a tracer [4]. However, the same method was not suitable for visualizing histamine owing to strong interference with the ubiquitous spermidine $[5,6]$. The first direct evidence for the existence of histaminergic neurons did not occur until the 1980s, with the development of immunohistochemistry using antibodies against histamine [7] and histidine decarboxylase [8]. All histaminergic neurons are localized in the tuberomammillary nucleus (TMN) of the posterior hypothalamus $[7,8]$, which is also the location of histidine decarboxylase (HDC) immunoreactivity [9], an

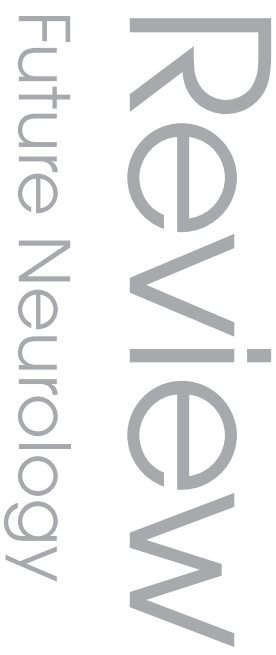

\footnotetext{
Keywords

- acetylcholine = antagonists/

inverse agonist = dopamine

- histamine $\mathrm{H}_{3}$ receptor

- microdialysis

- neuroprotection

- post-traumatic stress disorder

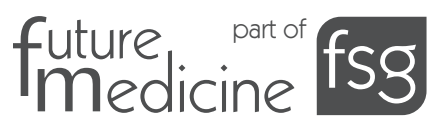


essential determinant of brain histamine levels $[10,11]$. They project to almost all regions of the CNS [12], mostly unmyelinated fibers that, with the exception of the mesencephalic trigeminal nucleus [13], do not form synaptic contacts but present diffuse varicosities containing synaptic vesicles [14,15]. This peculiarity suggests that histamine may act as a local hormone, affecting not only neuronal but also glial activity, and blood vessel tone [16]. Consistently, cultured astrocytes from rat cerebral cortex display histamine receptors identical to those present on neuronal cells $[17,18]$. This morphological feature (a compact cell group with widely distributed fibers) resembles that of other biogenic amine systems, such as norepinephrine or serotonin, thus suggesting that histaminergic neurons may regulate several central functions.

\section{Histamine receptors as therapeutic drug targets}

Histamine exerts its effect by interacting with specific receptors: $\mathrm{H}_{1} \mathrm{R}[19], \mathrm{H}_{2} \mathrm{R}$ [20], $\mathrm{H}_{3} \mathrm{R}$ [21] and $\mathrm{H}_{4} \mathrm{R}$ [22], as well as with the polyamine-binding site on the NMDA-receptor complex [23]. All four histaminergic receptor subtypes belong to the rhodopsin-like family of G-protein-coupled receptors (GPCRs) [24,25], and are functionally expressed on neurons in the mammalian CNS $[6,26]$. The first two members of the histamine receptor family, $\mathrm{H}_{1} \mathrm{R}$ and $\mathrm{H}_{2} \mathrm{R}$, are wellestablished drug targets, and antagonists of these receptors have been successfully used as blockbuster drugs for treating allergic conditions and gastric ulcers. The $\mathrm{H}_{4} \mathrm{R}$ is primarily distributed in immune cells, where it mediates immune and inflammatory responses [27]. However, the recent description of a functional expression of $\mathrm{H}_{4} \mathrm{R}$ on human and rodent neurons $[26,28]$ is still waiting for a better functional characterization. The discovery of the $\mathrm{H}_{3} \mathrm{R}$ by Jean-Charles Schwartz and his group in Paris, France, has been a real breakthrough in histamine research [21]. This receptor is largely confined to the nervous system [29], where it acts as a presynaptic autoreceptor that restricts histamine release, as well as synthesis both in vitro [21] and in vivo [30-33]. The $\mathrm{H}_{3} \mathrm{R}$ is located also on histaminergic somata, where it provides a tonic inhibition of firing [34]. Moreover, the presence of the $\mathrm{H}_{3} \mathrm{R}$ is not restricted to histaminergic neurons [35-37]. Accordingly, $\mathrm{H}_{3} \mathrm{Rs}$ also act as heteroreceptors, modulating the release of several neurotransmitters [6], including acetylcholine (Ach) [38,39], dopamine [40], norepinephrine [41] and serotonin $[42,43]$ from brain regions crucial for the maintenance of alertness or the storage of information [1]. $\mathrm{H}_{3} \mathrm{R}$ signaling is mediated through $\mathrm{G}_{\mathrm{i} / \mathrm{o}}$ proteins, negative coupling to adenylyl cyclase, and also through other signaling cascades, such as the activation of phospholipase A2, as well as protein kinase and PI3K pathways, which activate extracellular signal-regulated kinases and Akt and, subsequently, inhibit the action of glycogen synthase kinase $3 \beta[29,44]$.

Network analyses of the brain and its dysfunction suggest that agents with multiple and complementary modes of action are more likely to show broad-based efficacy against core and comorbid symptoms. Thus, the regulatory role in the release of histamine and other neurotransmitters makes the $\mathrm{H}_{3} \mathrm{R}$ an attractive target for therapies of CNS disorders, and $\mathrm{H}_{3} \mathrm{R}$ ligands are good therapeutic candidates for their simultaneous exploitation of multiple neuronal systems $[45,46]$. Consistent with the widespread distribution throughout the entire CNS of histaminergic fibers [47,48], brain histamine is, directly or indirectly, involved in a variety of basic homeostatic and higher brain functions, such as the sleep-wake cycle, appetite, nociception, cognition and emotion $[1,6] . \mathrm{H}_{3} \mathrm{R}$ antagonists/inverse agonists have been shown to increase wakefulness, improve cognitive performances and reduce bodyweight in animal models [6]. Such findings hint at the potential use of these compounds for the treatment of Alzheimer's disease (AD) and other dementias, attention-deficit hyperactivity disorder (ADHD), cognitive deficits in schizophrenia, obesity and sleep disorders [45,49-51]. Thus, it is not surprising that much effort is focused on the development of clinically suitable $\mathrm{H}_{3} \mathrm{R}$ antagonists/inverse agonists by academic and industrial laboratories [45,51,52]. As a result, more and more $\mathrm{H}_{3} \mathrm{R}$ antagonists/inverse agonists, such as ABT-239 [4-(2-\{2-[( $\left.{ }_{2} \mathrm{R}\right)-2$-methylpyrrolidinyl] ethyl\}-benzofuran-5-yl) benzonitrile]; BF2.649 (tiprolisant/pitolisant; 1-\{3-[3-(4-chlorophenyl) propoxy] propyl\} piperidine, hydrochloride; GSK239512 (structure not disclosed); JNJ-17216498 (structure not disclosed); MK-0249 (structure not disclosed) and PF-03654746 (trans- $N$-ethyl-3fluoro-3-[3-fluoro-4-(pyrrolidin-1-ylmethyl)phenyl]cyclobutanecarboxamide), progress through the clinic for a variety of conditions, including ADHD, cognitive disorders, hyperalgesia, narcolepsy and schizophrenia [45].

\section{Characteristics of the $\mathrm{H}_{3} \mathrm{R}$}

The $\mathrm{H}_{3} \mathrm{R}$ is largely confined to the nervous system, and the highest levels were found in the cerebral cortex, hippocampus, basal ganglia and 
hypothalamus [36,37]. This receptor has multiple splice variants. Not all isoforms appear to be functional, and some of them might regulate functional isoforms by associating with them $[53,54] . \mathrm{H}_{3} \mathrm{Rs}$ are members of the seventransmembrane receptor superfamily [55] and couple to $G_{i / o}$ proteins [56]. Their stimulation restricted the influx of calcium ions [57], inhibited adenylate cyclase [55], and increased extracellular signal-related kinase (ERK) phosphorylation in receptor-transfected cells [58]. All histamine receptors displayed a high degree of constitutive (agonist-independent) activity, which occurred in human, rat and mouse recombinant receptors expressed at physiological concentrations [59-62] . Of note, constitutive activity of native $\mathrm{H}_{3} \mathrm{Rs}$ seems one of the highest among the GPCRs in the brain [63]. Constitutively active $\mathrm{H}_{3} \mathrm{Rs}$ presumably regulate the release of neuronal histamine [61]; therefore, several $\mathrm{H}_{3} \mathrm{R}$ antagonists (e.g., clobenpropit, thioperamide and ciproxifan) that block constitutive activity are being reclassified as inverse agonists, a concept that may have clinical relevance. Indeed, either inverse agonists or neutral antagonists may be favorable for different therapeutic applications.

\section{Therapeutic potential of $\mathrm{H}_{3} \mathrm{R}$ antagonists/inverse agonists in cognitive \& emotional disorders}

Considerable interest was raised by reports that pharmacological blockade of $\mathrm{H}_{3}$ Rs exerted procognitive effects in a variety of animal tasks analyzing different types of memory, which should be taken as proof of concept. In the social memory $[64,65]$, rats treated with $\mathrm{H}_{3} \mathrm{R}$ antagonists/inverse agonists performed better than controls in the five-trial inhibitory avoidance task $[66,67]$ and the five-choice serial reactiontime test $[68]$. Further studies indicated that both imidazole and nonimidazole $\mathrm{H}_{3} \mathrm{R}$ antagonists/ inverse agonists exerted procognitive effects in cognitively impaired animals, as observed in senescence-accelerated mice or scopolamineimpaired rats challenged in a passive-avoidance response [69,70], scopolamine-impaired rats tested in object recognition $[49,70,71]$ or the elevated plusmaze paradigm [72], and MK-801-treated rats evaluated in the radial maze [73]. Administration of nonimidazole $\mathrm{H}_{3} \mathrm{R}$ antagonists/inverse agonists, A-304121 or A-317920, improved cognitive performances in spontaneously hypertensive rat pups that were normotensive during early development, but exhibited many cognitive impairments $[66,67]$. Certainly, such a model is clinically very relevant, as deficits are genetic in origin and do not require pharmacological or surgical intervention. Although another report provided some contrasting data, as $\mathrm{H}_{3} \mathrm{R}$ antagonists/inverse agonists impaired object recognition in wild-type and Apoe $e^{-1-}$ mice [74], these findings may be relevant to predict the potential of $\mathrm{H}_{3} \mathrm{R}$ antagonists/inverse agonists in ameliorating cognitive dysfunctions in humans [67]. In this regard, the presence of $\left[{ }^{3} \mathrm{H}\right] \mathrm{GSK} 189254-$ labeled $\mathrm{H}_{3} \mathrm{Rs}$ in hippocampal and cortical sections from patients with advanced $\mathrm{AD}$ is important [75], and suggests the persistence of $\mathrm{H}_{3} \mathrm{Rs}$, even in severe $\mathrm{AD}$.

If cognitive deficits are related to reduced availability of ACh in the synaptic cleft [76], increase of ACh release in the prefrontal cortex exerted by $\mathrm{H}_{3} \mathrm{R}$ antagonists/inverse agonists could account for the procognitive effects produced by these compounds, at least in short-term memory paradigms with important cortical cholinergic components, such as object recognition [77] and a passive-avoidance response [78]. Indeed, $\mathrm{H}_{3} \mathrm{R}$ ligands modulate cortical ACh release in a bimodal fashion, and modify the expression of memories accordingly. Stimulation of cortical $\mathrm{H}_{3} \mathrm{Rs}$ inhibited local ACh release, and impaired object recognition and a passive-avoidance response [39]. Conversely, TMN perfusion with GSK189254 significantly increased the release of cortical ACh in freely moving rats, and counteracted amnesic effects produced by scopolamine administration in rats, as measured in object recognition [71]. Cortical ACh increase can be a consequence of the augmentation of histamine release in the nucleus basalis magnocellularis (NBM) elicited by intra-TMN administration of GSK189254 [71]. Indeed, histamine, by activating $\mathrm{H}_{1} \mathrm{Rs}$, depolarized the cell membrane and increased the tonic firing of NBM cholinergic neurons [79], which provide all cholinergic innervation to the cortex [80]. These findings are in keeping with the report that perfusion of the NBM with $\mathrm{H}_{3} \mathrm{R}$ antagonists/inverse agonists increases cortical ACh release [81]. $\mathrm{H}_{3} \mathrm{R}$ antagonists/inverse agonists also augment NBM histamine release by blocking local $\mathrm{H}_{3}$-autoreceptors (FIGURE 1) [71,82]. A comparable enhancement of cortical ACh was also observed in response to systemic administration of several nonimidazole $\mathrm{H}_{3} \mathrm{R}$ antagonists/inverse agonists, such as ABT-239 [65], BF2.649 [83] or GSK189254 [84]. Neuronal alterations associated to cognitive deficits are not restricted to the cholinergic systems, as many neurotransmitter systems, including dopamine, contribute to specific aspects of cognition. Therefore, it is important to point out that systemic administration 


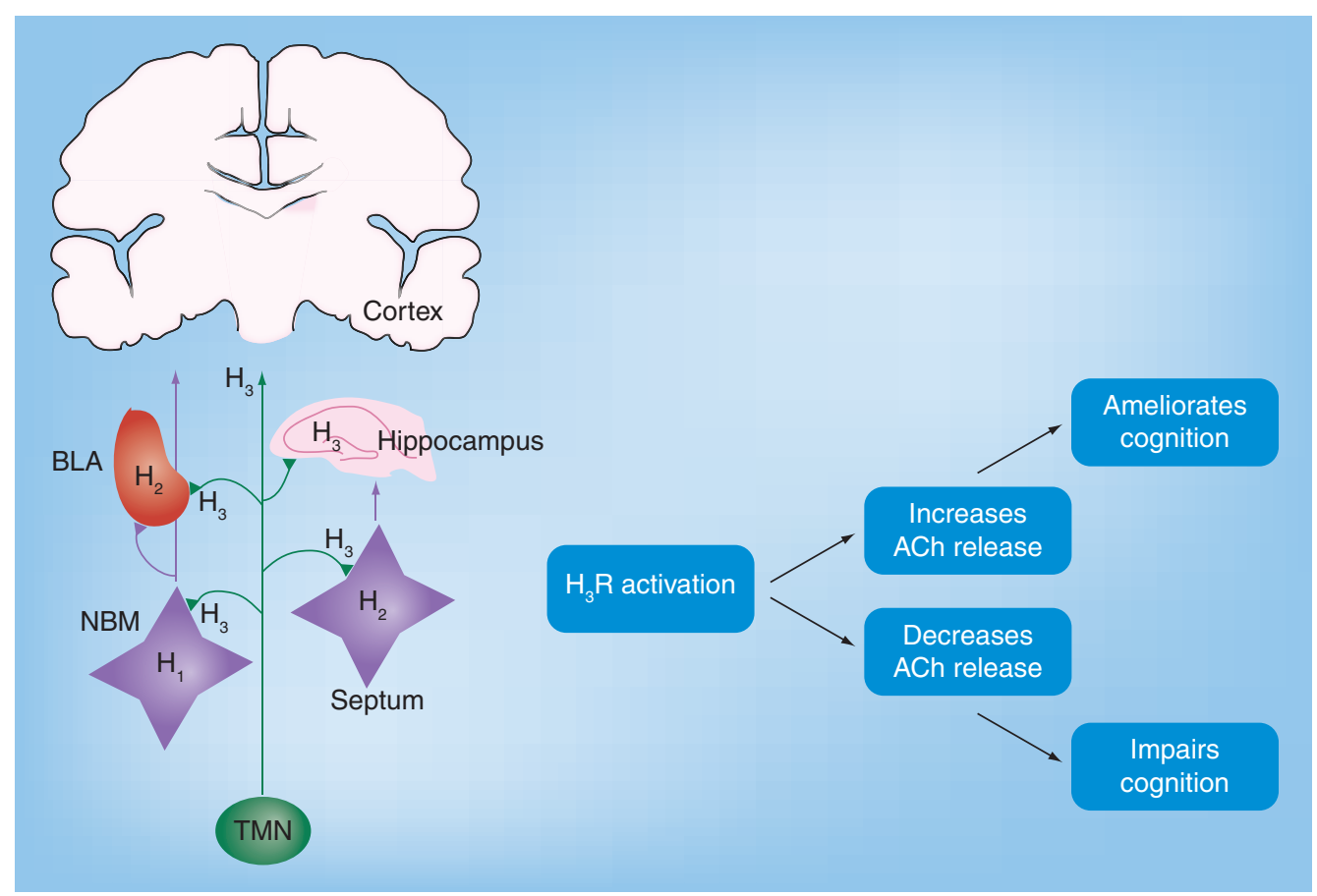

Figure 1. Cholinergic neurotransmission represents an essential neurophysiological component in attentional information processing. $\mathrm{H}_{3}$ receptors modulate $\mathrm{ACh}$ release with different modalities in different brain regions.

ACh: Acetylcholine; BLA: Basolateral amygdala; NBM: Nucleus basalis magnocellularis; TMN: Tuberomamillaris nucleus.

of ABT-239 [65] or BF2.649 [83] also increases the release of cortical dopamine. However, $\mathrm{H}_{3} \mathrm{R}$ antagonists/inverse agonists failed to increase dopamine release from other regions, such as the striatum [65] or the nucleus accumbens [71], and these observations may provide the rational basis for clinical indication in disorders such as schizophrenia or ADHD.

Interactions between the histaminergic and cholinergic systems serve as one of the physiological correlates for learning and remembering; however, $\mathrm{H}_{3} \mathrm{R}$ s modulate $\mathrm{ACh}$ release with modalities that differ according to regional architectural constraints, to their role as autoor hetero-receptors, and to the distinct actions that histamine exerts by activating different receptor subtypes (Figure 1). It is of note that basolateral amygdala (BLA) perfusion with $\mathrm{H}_{3} \mathrm{R}$ agonists increases, whereas with $\mathrm{H}_{3} \mathrm{R}$ antagonists/inverse agonists decreases, $\mathrm{ACh}$ release from the BLA [85,86]. These drugs presumably impact on inhibitory $\mathrm{H}_{3}$-autoreceptors, as BLA $\mathrm{H}_{3} \mathrm{R}$ receptor binding was strictly associated with the presence of histaminergic fibers [87]. Consistently, BLA perfusion with $\mathrm{H}_{3} \mathrm{R}$ antagonists/inverse agonists increased endogenous histamine release [88], which, in turn, activated postsynaptic $\mathrm{H}_{3} \mathrm{Rs}$ and inhibited $\mathrm{ACh}$ release [85]. The BLA receives the most abundant histaminergic innervation in the brain [89], and displays both high $\mathrm{H}_{3} \mathrm{R}$ binding and its gene transcripts [90]. Crucial neural changes mediating emotional memory occur in the BLA [91,92]. Emotional memory may be assessed with contextual fear conditioning, in which experimental animals learn to associate a mild electrical shock to the foot with the environment where they receive the punishment. A critical event for aversive memory consolidation is the activation of muscarinic receptors within the $\mathrm{BLA}[85,86,93]$. In this regard, it is relevant that BLA perfusion with $\mathrm{H}_{3} \mathrm{R}$ antagonists/inverse agonists impaired [85], whereas with $\mathrm{H}_{3} \mathrm{R}$ agonists ameliorated, expression of this form of associative memory [86]. These results contrast with the findings in the cortex. Nevertheless, since BLA is engaged in the development of mood disorders associated with extreme emotional traumas, the use of $\mathrm{H}_{3} \mathrm{R}$ antagonists/inverse agonists that weaken traumatic memories may be proposed to alleviate disorders such as post-traumatic stress disorder (PTSD), panic attacks, specific phobias and generalized anxiety.

Brain histamine affects emotional memory, eliciting ERK2 phosphorylation in hippocampal CA3 pyramidal cells, an event that is crucial for the consolidation of contextual fear memory [94]. 


\section{Arousal elicited by $\mathrm{H}_{3} \mathrm{R}$ antagonists/ inverse agonists \& its contribution to procognitive effects}

Cognition is a complex phenomenon involving the integration of multiple neurological activities, among which, arousal is crucial [95,96]. Histamine is, along with orexin, one of the major wake-promoting neurotransmitters in the CNS [97], as histidine decarboxylase-knockout mice that lack histamine are unable to remain awake when high vigilance is required [98]. In addition, narcoleptic dogs show histamine deficiency [99]. It is known that histaminergic neurons fire at higher frequency during wakefulness than during sleep [100]. Moreover, histamine is responsible for cortical EEG desynchronization [97], a salient sign of wakefulness [1,101]. Brain histamine elicits cortical activation both directly, through excitatory interactions with cholinergic corticopetal neurons originating from the substantia innominata [102] and the NBM [81], and indirectly through stimulation of cholinergic neurons in the mesopontine tegmentum, which activate thalamo- and hypothalamocortical circuitries [103] $\mathrm{H}_{3} \mathrm{R}$ blockade by local perfusion of thioperamide into the TMN increased the time spent in wakefulness, along with the release of TMN histamine in freely moving rats [82], thus suggesting that they, by increasing arousal, may enhance attention and improve cognitive performances. However, several $\mathrm{H}_{3} \mathrm{R}$ antagonists/ inverse agonists produced cognitive-enhancing effects at much lower doses than those required to elicit a robust wake enhancement $[65,67]$.
For example, ABT-239 produced no detectable change in slow-wave EEG at $30 \mathrm{mg} / \mathrm{kg}$, whereas it was effective in social recognition at $0.01 \mathrm{mg} / \mathrm{kg}$ [65]. Consistently, for ciproxifan, thioperamide or GSK189254, only a relatively low level of cumulative wake activity was linearly correlated with up to $80 \%$ of the receptor occupancy, and an abrupt break from linearity, along with a robust increase of waking activity, was observed at doses that produced greater than $80 \%$ occupancy [104]. High or low levels of $\mathrm{H}_{3} \mathrm{R}$ occupancy may express activities mechanistically different, and $\mathrm{H}_{3} \mathrm{R}$ antagonists/inverse agonists procognitive actions may not relate to increased arousal. Thus, lower dosage might be used to address $\mathrm{H}_{3} \mathrm{R}$ antagonists/inverse agonists actions, especially towards cognition. This is an important issue, since nocturnal sleep should, ideally, not be disturbed by drug therapies. Nevertheless, at least at higher dosage, this class of drugs constitutes a novel effective treatment of narcolepsy and excessive daytime sleepiness (EDS), and this contention is supported by both preclinical and clinical data. Indeed, acute administration of GSK189254 reduced narcoleptic episodes in orexin-knockout mice [105]. Moreover, in a pilot single-blind clinical trial on 22 patients diagnosed with narcolepsy receiving a placebo for 1 week, followed by tiprolisant (BF2.649) for a second week, the Epworth sleepiness scale (ESS) score was reduced from a baseline value of 17.6 by 1.0 with the placebo $(p>0.05)$, and 5.9 with tiprolisant $(\mathrm{p}<0.001)$ [106]. EDS, unaffected under placebo, was nearly suppressed on the last days

Table 1. Histamine $\mathrm{H}_{3}$ receptor ligands in clinical trials for the treatment of CNS disorders.

\begin{tabular}{|c|c|c|c|}
\hline Disorder & Compound & Condition & Phase \\
\hline \multirow[t]{2}{*}{ Alzheimer's disease } & GSK-239512 & Mild/moderate & ॥ \\
\hline & MK-0249 & & $\|$ \\
\hline \multirow[t]{4}{*}{ Narcolepsy } & BF2.649 (tiprolisant/pitolisant) & Sleepiness & III \\
\hline & BF2.649 (tiprolisant/pitolisant) & Cataplexy & III \\
\hline & PF-03654746 & Sleepiness & II \\
\hline & MK-0249 & Sleepiness in patients with OSA/HS & $\|$ \\
\hline \multirow[t]{2}{*}{ Attention-deficit hyperactivity disorder } & MK-0249 & & II \\
\hline & PF-03654746 & & $\|$ \\
\hline Schizophrenia & BF2.649 (tiprolisant/pitolisant) & Cognitive impairment & $\|$ \\
\hline Epilepsy & BF2.649 (tiprolisant/pitolisant) & Photosensitive epilepsy & $\|$ \\
\hline
\end{tabular}


of tiprolisant dosing [106]. Very few human data on cognition and waking behavior are available (TABle 1), hence preclinical studies can be taken as proof of concept. The cognitive-enhancing effects of the $\mathrm{H}_{3} \mathrm{R}$ antagonist GSK239512 are being evaluated in patients with mild-to-moderate $\mathrm{AD}$. The $\mathrm{H}_{3} \mathrm{R}$ antagonist PF-03654746 is being evaluated for its effectiveness in the treatment of ADHD, and advanced to Phase II clinical trials for its efficacy in improving alertness and wakefulness in patients with EDS. BF2.649 also reduced EDS in narcoleptic patients, and currently running clinical trials are showing that it is a very promising alerting drug in Parkinson's disease [107].

\section{$\mathrm{H}_{3} \mathrm{Rs}$ \& neuroprotection}

Much of the recent interest in developing new ligands of the $\mathrm{H}_{3} \mathrm{R}$ stems from the potential use of $\mathrm{H}_{3} \mathrm{R}$ antagonists in controlling feeding behaviour, disorders of the sleep-wake cycle and cognitive impairments associated with $\mathrm{AD}$ or Parkinson's disease (reviewed in [108]). However, there are potential therapeutic applications for $\mathrm{H}_{3} \mathrm{R}$ agonists as well. $\mathrm{H}_{3} \mathrm{R}$ activation in the $\mathrm{CNS}$ results in lower hypothalamic histamine release, and an $\mathrm{H}_{3} \mathrm{R}$ agonist may be used to treat insomnia [109]. In addition, Hough and coworkers revealed an antinociceptive role for spinal histamine $\mathrm{H}_{3} \mathrm{R}$ [110]. In the past years, several studies have hinted at a role of the $\mathrm{H}_{3} \mathrm{R}$ in neuroprotection. The first clear indication of how 'plastic' the brain histaminergic system is following injury, was provided by Panula and collaborators. They showed that $\mathrm{H}_{3} \mathrm{R}$ mRNA is upregulated in the rat caudate and putamen following induction of transient global cerebral ischemia [111], or in the rat cortex following kainic acid-induced seizures [112], although with different time courses and recovery. A more recent paper published by the same group elegantly demonstrated that histamine protects hippocampal neurons from damage induced by kaininc acid in organotipic cocultures of hypothalamic and hippocampal tissue [113]. The hypothalamic histaminergic innervation of hippocampal neurons provides the neuroprotective effect and, presumably, the blockade of presynaptic autoinhibitory $\mathrm{H}_{3} \mathrm{R}$ ameliorates the protective effect of histaminergic neurons. We recently showed that $\mathrm{H}_{3} \mathrm{R}$ agonists activate antiapoptotic pathways, such as the PI3K/Akt/GSK-3 $\beta$ pathway [44]. The Akt pathway has been implicated in regulating several important cellular processes, including cell plasticity and survival, proliferation and metabolism. Akt promotes neuronal cell survival and opposes apoptosis by a variety of routes (e.g., modulating inhibitors of apoptosis, such as Bcl-2 and $\mathrm{Bcl}-\mathrm{x}$ ). Indeed, in our model $\mathrm{H}_{3} \mathrm{R}$ agonists increased the expression of $\mathrm{Bcl}-2$, and decreased the expression of pro-apoptotic elements, such as caspase-3, following neurotoxic insults in cultured murine cortical neurons [44]. Hence, stimulation of $\mathrm{H}_{3} \mathrm{R}$ protects cortical neurons from NMDA-induced neurotoxic insults, and this observation may have relevance in the prevention of, for instance, ischemic neuronal damage or neurodegenerative diseases. As a matter of fact, schizophrenic patients display impaired Akt/GSK-3 $\beta$ signaling [114], and evidence points to a key role for GSK-3 $\beta$ in promoting neurodegeneration [15]. GSK3 is involved in a cascade of events, such as hyperphosphorylation of tau protein, increased production of $\beta$-amyloid and local cerebral inflammatory responses that may culminate in $\mathrm{AD}$ [116]. In this regard, binding studies showed that the expression of $\mathrm{H}_{3} \mathrm{R}$ is spared in the brain of AD patients [84]. To fully understand the impact of $\mathrm{H}_{3} \mathrm{R}$-induced activation of antiapoptotic pathways in the CNS, in vivo experiments are necessary, even more so as $\mathrm{H}_{3} \mathrm{R}$ antagonists are now viewed as potential therapeutics for schizophrenia [83] and AD [84].

\section{Heterogeneity of histaminergic neurons}

In comparable architecture of noradrenergic, dopaminergic and serotonergic systems [117,118], somata of histaminergic neurons are restricted to discrete cell clusters in the hypothalamic TMN, and send their axons to innervate nearly the entire CNS [7,8]. Cathecolaminergic and serotonergic nuclei are comprised of distinct compartments with respect to projection fields, as distinct sets of axons innervating separate brain regions originate from separate subgroups of noradrenergic (A1-A7), dopaminergic (A8-A17) and serotonergic (B1-B9) neurons [117,118]. This does not seem to be the case for the histaminergic system, as retrograde tracers injected into different CNS regions labeled histaminergic somata scattered throughout the TMN without a strict topographical pattern $[9,12,119]$. Noradrenergic, dopaminergic and serotonergic patterns imply independent functions of sets of neurons according to their origin and terminal projections. On the contrary, the morphological feature of the histaminergic system is consistent with the hypothesis of a single regulatory network for whole-brain activity, which modulates general states of metabolism and consciousness, rather than processing specific functions [16]. However, very recently, direct evidence demonstrated that 
histaminergic neurons are also organized into functionally distinct circuits, impinging on different brain regions and displaying selective control mechanisms. Using the double-probe microdialysis technique in freely moving rats, it was observed that histaminergic neurons established distinct pathways related to independent functions according to their terminal projections, and to their sensitivity to $\mathrm{H}_{3} \mathrm{R}$ antagonists/ inverse agonists or $\mathrm{GABA}_{\mathrm{A}}$-receptor $\left(\mathrm{GABA}_{\mathrm{A}}-\mathrm{R}\right)$ antagonists [71,82]. GABA $-\mathrm{R}$ activation directly inhibits histaminergic cell firing rate $[120,121]$, whereas $\mathrm{GABA}_{\mathrm{A}}-\mathrm{R}$ inhibition increases TMN histamine release significantly [122]. Depending on $\mathrm{GABA}_{\mathrm{A}}-\mathrm{R}$-subunit expressions, histaminergic neurons displayed different sensitivities to GABA $[123,124]$. This may account for the functional heterogeneity of GABAergic responses displayed by histaminergic neurons following stimulation of the diagonal band of Broca, the antero-lateral hypothalamus, or the lateral preoptic area [120]. The finding that intrahypothalamic perfusion of bicuculline increased histamine release from the TMN, the nucleus accumbens and cortex, but not from the striatum [82], indicates that sensitivity to bicuculline relates to TMN neurons heterogeneity with respect to projection fields.

Application of imidazole or nonimidazole $\mathrm{H}_{3} \mathrm{R}$ antagonists/inverse agonists locally into the TMN significantly increased histamine release from the TMN, the prefrontal cortex and the NBM, but not from the striatum or nucleus accumbens [71,82]. These findings indicate that histamine neurons projecting to the dorsal striatum and nucleus accumbens were insensitive to blockade of $\mathrm{H}_{3} \mathrm{Rs}$ [71,82]. Spatial segregation caused by probe localization does not explain why histaminergic neurons projecting to the striatum or nucleus accumbens do not respond to $\mathrm{H}_{3} \mathrm{R}$ antagonists/inverse agonists. Infact, bicuculline administered into the TMN significantly augmented histamine release from the nucleus accumbens [82], and TMN perfusion with cannabinoid 1-receptor agonists increased histamine release from the dorsal striatum [122], confirming the existence of histaminergic afferents to the striatum. Furthermore, retrograde tracing with dye injections into the striatum or prefrontal cortex labeled most histaminergic somata within the same area, the medial part of the ventral TMN [119]. This proximity suggests that the compounds administered through the microdialysis probe indiscriminately affected histaminergic cells projecting to the striatum and prefrontal cortex. Interestingly, previous studies showed that following GSK189254 administration, activation of c-fos occurred in cortical areas and the TMN, but not in striatum [84]. Moreover, local perfusion of the striatum with $\mathrm{H}_{3} \mathrm{R}$ antagonists/inverse agonists did not alter spontaneous histamine release [71,82], suggesting that the entire somatodendritic domain of histaminergic neurons projecting to this region were insensitive to $\mathrm{H}_{3} \mathrm{R}$ blockade. Since the magnitude of neuronal responses to extracellular signals might also depend on different receptor numbers at the membrane, it is important to underline that in the TMN, some HDC-positive cells displayed very low levels of $\mathrm{H}_{3} \mathrm{R}$ immunoreactivity [82], although no evidence demonstrates that these cells are the ones innervating the nucleus accumbens or striatum. On the other hand, histamine increases in the prefrontal cortex and NBM were probably caused by discharge potentiation of histamine neurons, sending afferents to these regions, in analogy to TMN perfusion with prostaglandin $E_{2}$ [125], orexin-A [126] or endocannabinoids [122].

These observations suggest that the histaminergic system is organized into distinct circuits modulated by selective mechanisms. This could imply independent functions of subsets of histaminergic neurons according to their respective origin and terminal projections.

\section{Conclusion}

A wide variety of studies agree that the neuronal histaminergic system regulates some forms of cognition, and, inevitably, reports that pharmacological blockade of central $\mathrm{H}_{3} \mathrm{Rs}$ exerts procognitive activity in several cognitive tasks have raised considerable interest. Advances in molecular pharmacology are uncovering the extraordinary complexity of the $\mathrm{H}_{3} \mathrm{R}$ : it shows functional constitutive activity, polymorphisms in humans and rodents - with a differential distribution of splice variants in the CNS, and potential coupling to different intracellular signal-transduction mechanism. Thus, it will be a great challenge in the years to come to develop ever-more-selective agonists, inverse agonists, pure antagonists of the $\mathrm{H}_{3} \mathrm{R}$, as well as ligands for its various isoforms. All histaminergic neurons are believed to express $\mathrm{H}_{3} \mathrm{Rs}$, and responses to $\mathrm{H}_{3} \mathrm{R}$ ligands are a criterion for their identification in vitro. Contrary to this general assumption, it has been recently reported that histamine neurons projecting to the striatum and nucleus accumbens are insensitive to thioperamide, an $\mathrm{H}_{3} \mathrm{R}$ antagonist, thus suggesting that histamine neurons are more functionally heterogeneous than previously thought. Although further 


\section{Executive summary}

\section{Histamine is a neurotransmitter}

- All histaminergic neurons are localized in the tuberomammillary nucleus (TMN) of the posterior hypothalamus and project to almost all regions of the CNS, mostly unmyelinated fibers that, with the exception of the mesencephalic trigeminal nucleus, do not form synaptic contacts, but present diffuse varicosities containing synaptic vesicles.

- This morphological feature, a compact cell group with widely distributed fibers, resembles that of other biogenic amines systems, such as norepinephrine or serotonin, thus suggesting that histaminergic neurons may also regulate several central functions.

\section{Histamine receptors as therapeutic drug targets}

- All four histaminergic receptor subtypes $\left(\mathrm{H}_{1} \mathrm{R}, \mathrm{H}_{2} \mathrm{R}, \mathrm{H}_{3} \mathrm{R}\right.$ and $\left.\mathrm{H}_{4} \mathrm{R}\right)$ belong to the rhodopsin-like family of $\mathrm{G}$-protein-coupled receptors (GPCRs), and are functionally expressed on neurons in the mammalian CNS.

- The $\mathrm{H}_{1} \mathrm{R}$ and $\mathrm{H}_{2} \mathrm{R}$ are well-established drug targets, and antagonists of these receptors have been successfully used as blockbuster drugs for treating allergic conditions and gastric ulcers. $\mathrm{H}_{4} \mathrm{Rs}$ are primarily distributed in immune cells where they mediate immune and inflammatory responses.

- The $\mathrm{H}_{3} \mathrm{R}$ acts as a presynaptic autoreceptor that restricts histamine release as well as synthesis, and as a heteroreceptor, modulating the release of several neurotransmitters, including acetylcholine (ACh), dopamine, norepinephrine and serotonin.

- The regulatory role in the release of histamine and other neurotransmitters makes the $\mathrm{H}_{3} \mathrm{R}$ an attractive target for therapies of CNS disorders, and $\mathrm{H}_{3} \mathrm{R}$ ligands are good therapeutic candidates for their simultaneous exploitation of multiple neuronal systems.

\section{Characteristics of the $\mathbf{H}_{3} \mathbf{R}$}

- The $\mathrm{H}_{3} \mathrm{R}$ is largely confined to the nervous system.

- Molecular pharmacology is uncovering the extraordinary complexity of the $\mathrm{H}_{3} \mathrm{R}$ - it shows functional constitutive activity, polymorphisms in humans and rodents with a differential distribution of splice variants in the CNS, and potential coupling to different intracellular signal-transduction mechanisms.

- Constitutive activity of native $\mathrm{H}_{3} \mathrm{Rs}$ appears to be one of the highest among the GPCRs in the brain.

\section{Therapeutic potentials of $\mathbf{H}_{3} \mathrm{R}$ antagonists/inverse agonists in cognitive \& emotional disorders}

- Considerable interest was raised by reports that pharmacological blockade of $\mathrm{H}_{3} \mathrm{Rs}$ exerted procognitive effects in a variety of animal tasks analyzing different types of memory.

- Increase of ACh release in the prefrontal cortex exerted by $\mathrm{H}_{3} \mathrm{R}$ antagonists/inverse agonists could account for the procognitive effects produced by these compounds. Neuronal alterations associated to cognitive deficits are not restricted to the cholinergic systems, as many neurotransmitter systems, including dopamine, contribute to specific aspects of cognition. Therefore, it is important to point out that systemic administration of $\mathrm{H}_{3} \mathrm{R}$ antagonists/inverse agonists increases the release of cortical dopamine but fails to increase dopamine release from other regions, such as the striatum or the nucleus accumbens.

- These observations may provide the rational basis for clinical indication in disorders, such as Alzheimer's disease and other dementias, schizophrenia or attention-deficit hyperactivity disorder.

- The use of $\mathrm{H}_{3} \mathrm{R}$ antagonists/inverse agonists that weaken traumatic memories may help to alleviate disorders such as post-traumatic stress syndrome, panic attacks, specific phobias and generalized anxiety.

\section{Arousal elicited by $\mathrm{H}_{3} \mathrm{R}$ antagonists/inverse agonists \& its contribution to procognitive effects}

- It is known that histaminergic neurons fire at a higher frequency during wakefulness than during sleep, and are responsible for cortical EEG desynchronization, a salient sign of wakefulness.

- This class of drugs constitutes a novel effective treatment of narcolepsy and excessive daytime sleepiness, and this contention is supported by both preclinical and clinical data.

- BF2.649 (tiprolisant/pitolisant) reduced excessive daytime sleepiness in narcoleptic patients, and current clinical trials are showing that it is a very promising alerting drug in Parkinson's disease.

\section{$\mathbf{H}_{3} \mathbf{R s}$ \& neuroprotection}

- Several studies have hinted at a role of the $\mathrm{H}_{3} \mathrm{R}$ in neuroprotection. $\mathrm{H}_{3} \mathrm{R}$ mRNA is upregulated in the rat caudate and putamen following induction of transient global cerebral ischemia, or in the rat cortex following kainic acid-induced seizures.

= $\mathrm{H}_{3} \mathrm{R}$ agonists activate antiapoptotic pathways, such as the PI3K/Akt/GSK-3 $\beta$ pathway.

\section{Heterogeneity of histaminergic neurons}

- Histamine neurons established distinct pathways related to independent functions according to their terminal projections, and to their sensitivity to $\mathrm{H}_{3} \mathrm{R}$ antagonists/inverse agonists or $\mathrm{GABA}_{\mathrm{A}}$ receptor antagonists.

- This could imply independent functions of subsets of histaminergic neurons according to their respective origin and terminal projections. 
studies are required to understand the full implications of such functional heterogeneity of histaminergic neurons, the possibility that $\mathrm{H}_{3} \mathrm{Rs}$ control only some of those functions implies that $\mathrm{H}_{3} \mathrm{R}$-directed therapies may achieve selective effects with minimal side effects, and this may increase the interest for this class of drugs.

\section{Future perspective}

The $\mathrm{H}_{3} \mathrm{R}$ plays a regulatory role in the release of histamine and other neurotransmitters, making it an attractive target for CNS indications, including cognitive disorders, narcolepsy, ADHD and pain. The interest in this receptor as a potential drug target has produced great advancement in novel compound series with different properties, providing a variety of preclinical tools, as well as advancing several candidates into clinical trials. As increasing numbers of $\mathrm{H}_{3} \mathrm{R}$ antagonists/inverse agonists progress through the clinic for a number of potential indications, knowledge will be gained to define the profile of the ideal compound in terms of specificity, pharmacokinetic parameters, and both duration and magnitude of receptor occupancy. However, since recent evidence indicates that histaminergic neurons are heterogeneous and organized into functionally distinct circuits that influence different brain regions, and display selective control mechanisms, efforts will be focused towards the identification and pharmacological characterization of different compounds, each suitable for the treatment of specific disorders.

\section{Financial \& competing interests disclosure}

The authors have no relevant affiliations or financial involvement with any organization or entity with a financial interest in or financial conflict with the subject matter or materials discussed in the manuscript. This includes employment, consultancies, honoraria, stock ownership or options, expert testimony, grants or patents received or pending, or royalties.

No writing assistance was utilized in the production of this manuscript.

\section{Bibliography}

Papers of special note have been highlighted as:

- of interest

-. of considerable interest

1. Passani MB, Lin J-S, Hancock A, Crochet S, Blandina P: The histamine $\mathrm{H}_{3}$ receptor as a novel therapeutic target for cognitive and sleep disorders. Trends Pharmacol. Sci. 25(12), 618-625 (2004).

2. Kwiatkowski H: Histamine in nervous tissue. J. Physiol. 102, 32-41 (1943).

3. Green JP: Histamine and the nervous system. Fed. Proc. 23, 1095-1102 (1964).

- Green was a pioneer in proposing histamine as a neurotransmitter.

4. Carlsson A, Falck B, Hillarp NA, Thieme G, Torp A: A new histochemical method for visualization of tissue catecholamines. Med. Exp. Int. J. Exp. Med. 4, 123-125 (1961).

5. Green JP: Histamine. In: Handbook of Neurochemistry. Lajtha A (Ed.). Plenum, NY, USA 221-250 (1970).

6. Haas H, Sergeeva O, Selbach O: Histamine in the nervous system. Physiol. Rev. 88(3), 1183-1241 (2008).

- Comprehensive and very detailed review of histamine in the CNS. Haas contributed greatly to advancing knowledge in the field of neuronal histamine with his electrophysiological studies.

7. Panula P, Yang HY, Costa E: Histaminecontaining neurons in the rat hypothalamus. Proc. Natl Acad. Sci. 81, 2572-2576 (1984).
-. Along with [8], first anatomical identification of histaminergic neurons.

8. Watanabe T, Taguchi Y, Shiosaka S et al: Distribution of the histaminergic neuron system in the central nervous system of rats: a fluorescent immunohistochemical analysis with histidine decarboxylase as a marker. Brain Res. 295, 13-25 (1984).

-. Along with [7], first anatomical identification of histaminergic neurons.

9. Ericson H, Watanabe T, Köhler C: Morphological analysis of the tuberomammillary nucleus of the rat brain: delineation of subgroups with antibody against L-histidine decarboxylase as a marker. J. Comp. Neurol. 263, 1-24 (1987).

10. Green JP, Prell GD, Khandelwal JK, Blandina P: Aspects of histamine metabolism. Agents Actions 22, 1-15 (1987).

11. Kollonitsch J, Patchett AA, Marburg S et al.: Selective inhibitors of biosynthesis of aminergic neurotransmitters. Nature 274, 906-908 (1978).

12. Inagaki N, Toda K, Taniuchi I et al: : An analysis of histaminergic efferents of the tuberomammillary nucleus to the medial preoptic area and inferior colliculus of the rat. Exp. Brain Res. 80, 374-380 (1990).

13. Inagaki N, Yamatodani A, Shinoda K et al.: The histaminergic innervation of the mesencephalic nucleus of trigeminal nerve in the rat brain: a light and electron microscopic study. Brain Res. 418, 388-391 (1987).
14. Takagi H, Morishima Y, Matsuyama T, Hayashi $\mathrm{H}$, Watanabe $\mathrm{T}$, Wada $\mathrm{H}$ : Histaminergic axons in the neostriatum and cerebral cortex of the rat: a correlated light and electron microscope immunocytochemical study using histidine decarboxylase as a marker. Brain Res. 364, 114-123 (1986).

15. Michelsen K, Panula P: Subcellular distribution of histamine in mouse brain neurons. Inflamm. Res. 51(Suppl. 1), S46-S48 (2002).

16. Wada H, Inagaki N, Yamatodani A, Watanabe T: Is the histaminergic neuron system a regulatory center for whole-brain activity? Trends Neurosci. 14, 415-418 (1991).

17. Inagaki N, Fukui H, Taguchi Y, Wang N, Yamatodani A, Wada H: Characterization of histamine $\mathrm{H}_{1}$-receptors on astrocytes in primary culture: $\left[{ }^{3} \mathrm{H}\right]$ mepyramine binding studies. Eur. J. Pharmacol. 173, 43-51 (1989).

18. Carman-Krzan M, Lipnik-Stangelj M: Molecular properties of central and peripheral histamine $\mathrm{H}_{1}$ and $\mathrm{H}_{2}$ receptors. Pflugers Arch. 439, 131-132 (2000).

19. Ash ASF, Schild HO: Receptors mediating some actions of histamine. Br. J. Pharmac. Chemother. 27, 427-439 (1966).

20. Black JW, Duncan WM, Durant CJ, Ganellin CR, Parsons EM: Definition and antagonism of histamine $\mathrm{H}_{2}$-receptors. Nature 236, 385-390 (1972).

- Sir JW Black received the Nobel Prize for his discoveries in the field of the $\mathrm{H}_{2}$ receptor. 
21. Arrang JM, Garbarg M, Schwartz JC: Auto-inhibition of brain histamine release mediated by a novel class $\left(\mathrm{H}_{3}\right)$ of histamine receptors. Nature 302, 832-837 (1983).

- First demonstration of the $\mathrm{H}_{3}$ receptor. Schwartz and his group have made some of the most important contributions to the field of neuronal histamine.

22. Oda T, Morikawa N, Saito Y, Masuho Y, Matsumoto S: Molecular cloning and characterization of novel type of histamine receptor preferentially expressed in leukocytes. J. Biol. Chem. 275, 36781-36786 (2000).

23. Vorobjev VS, Sharonova IN, Walsh IB, Haas HL: Histamine potentiates $N$-methyl-Daspartate responses in acutely isolated hippocampal neurons. Neuron 11, 837-844 (1993).

24. Hill SJ, Ganellin CR, Timmerman HJM et al.: International union of Pharmacology. XIII: classification of histamine receptors. Pharmacol. Rev. 49, 253-278 (1997).

25. O'Reilly M, Alpert R, Jenkinson S et al.: Identification of a histamine $\mathrm{H}_{4}$ receptor on human eosinophils role in eosinophil chemotaxis. J. Recept. Signal Transduct. Res. 22, 431-448 (2002).

26. Connelly WM, Shenton FC, Lethbridge N et al:: The histamine $\mathrm{H}_{4}$ receptor is functionally expressed on neurons in the mammalian CNS. Br. J. Pharmacol. 157, 55-63 (2009).

27. Zhang M, Thurmond RL, Dunford PJ: The histamine $\mathrm{H}_{4}$ receptor: a novel modulator of inflammatory and immune disorders. Pharmacol. Ther. 113, 594-606 (2007).

28. Lethbridge NL, Chazot PL: Immunological identification of the mouse $\mathrm{H}_{4}$ histamine receptor on spinal cord motor neurons using a novel anti-mouse $\mathrm{H} 4$ antibody. Inflamm. Res. 59, S197-S198 (2009).

29. Leurs R, Bakker RA, Timmerman H, deEsch IJ: The histamine $\mathrm{H}_{3}$ receptor: from gene cloning to $\mathrm{H}_{3}$ receptor drugs. Nat. Rev. Drug Discov. 4(2), 107-120 (2005).

30. Arrang JM, Garbarg M, Lancelot JC et al: Highly-potent and selective ligands for histamine- $\mathrm{H}_{3}$ receptors. Nature 327, 117-123 (1987).

- First report of selective $\mathrm{H}_{3}$-receptor ligands.

31. Itoh Y, Oishi R, Nishibori M, Saeki K: Characterization of histamine release from the rat hypothalamus as measured by in vivo microdialysis. J. Neurochem. 56, 769-774 (1991).

32. Mochizuki T, Yamatodani A, Okakura K, Takemura M, Inagaki N, Wada $\mathrm{H}$ : In vivo release of neuronal histamine in the hypothalamus of rats measured by microdialysis. Naunyn-Schmiedeberg Arch. Pharmacol. 343, 190-195 (1991).
33. Prast H, Fisher HP, Prast M, Philippu A: In vivo modulation of histamine release by autoreceptors and muscarinic acetylcholine receptors in the rat anterior hypothalamus. Naunyn-Schmiedeberg Arch. Pharmacol. 350, 599-604 (1994).

34. Haas H, Panula P: The role of histamine and the tuberomamillary nucleus in the nervous system. Nat. Rev. Neurosci. 4, 121-130 (2003).

-35. Cumming P, Shaw C, Vincent SR: High affinity histamine binding site is the $\mathrm{H}_{3}$ receptor: characterization and autoradiographic localization in rat brain. Synapse 8, 144-151 (1991).

36. Pollard H, Moreau J, Arrang JM, Schwartz J-C: A detailed autoradiographic mapping of histamine $\mathrm{H}_{3}$ receptors in rat brain areas. Neuroscience 52, 169-189 (1993).

37. Martinez-Mir MI, Pollard H, Arrang JM et al:: Three histamine receptors $\left(\mathrm{H}_{1}, \mathrm{H}_{2}\right.$ and $\left.\mathrm{H}_{3}\right)$ visualized in the brain of human and non human primates. Brain Res. 526, 322-327 (1990).

38. Clapham J, Kilpatrick GJ: Histamine $\mathrm{H}_{3}$ receptors modulate the release of $\left[{ }^{3} \mathrm{H}\right]-$ acetylcholine from slices of rat entorhinal cortex: evidence for the possible existence of $\mathrm{H}_{3}$ receptor subtypes. Br. J. Pharmacol. 107 , 919-923 (1992).

39. Blandina P, Giorgetti M, Bartolini L R et al.: Inhibition of cortical acetylcholine release and cognitive performance by histamine $\mathrm{H}_{3}$ receptor activation in rats. Br. J. Pharmacol. 119, 1656-1664 (1996).

- Provided evidence of the interactions between acetylcholine and histamine in modulating cognitive processes.

40. Schlicker E, Fink K, Detzner M, Göthert M: Histamine inhibits dopamine release in the mouse striatum via presynaptic $\mathrm{H}_{3}$ receptors. J. Neural Transm. 93, 1-10 (1993).

41. Schlicker E, Fink K, Hinterhaner M, Göthert M: Inhibition of noradrenaline release in the rat brain cortex via presynaptic $\mathrm{H}_{3}$ receptors. Naunyn-Schmiedeberg Arch. Pharmacol. 340, 633-638 (1989).

42. Schlicker E, Betz R, Göthert M: Histamine $\mathrm{H}_{3}$ receptor-mediated inhibition of serotonin release in the rat brain cortex. Naunyn-Schmiedeberg Arch. Pharmacol. 337, 588-590 (1988).

43. Threlfell S, Cragg SJ, Kallo I, Turi GF, Coen CW, Greenfield SA: Histamine $\mathrm{H}_{3}$ receptors inhibit serotonin release in substantia nigra pars reticulata. J. Neurosci. 24(40), 8704-8710 (2004).

-44. Mariottini C, Scartabelli T, Bongers G et al.: Activation of the histaminergic $\mathrm{H}_{3}$ receptor induces phosphorylation of the Akt/GSK-3 $\beta$ pathway in cultured cortical neurons and protects against neurotoxic insults. J. Neurochem. 110(5), 1469-1478 (2009).
- Demonstration of $\mathbf{H}_{3}$ receptor involvement in neuroprotective mechanisms.

45. Gemkow MJ, Davenport AJ, Harich S, Ellenbroek BA, Cesura A, Hallett D: The histamine $\mathrm{H}_{3}$ receptor as a therapeutic drug target for CNS disorders. Drug Discov. Today 14, 509-515 (2009).

46. Tiligada E, Zampeli E, Sander K, Stark H: Histamine $\mathrm{H}_{3}$ and $\mathrm{H}_{4}$ receptors as novel drug targets. Expert Opin. Investig. Drug. 18, 1519-1531 (2009).

47. Inagaki N, Yamatodani A, Ando-Yamamoto M, Tohyama M, Watanabe T, Wada H: Organization of histaminergic fibers in the rat brain. J. Comp. Neurol. 273, 283-300 (1988).

48. Panula P, Flügge G, Fuchs E, Pirvola U, Auvinen S, Airaksinen MS: Histamineimmunoreactive nerve fibers in the rat brain. Brain Res. 484, 234-239 (1989).

49. Medhurst AD, Briggs MA, Bruton Get al.: Structurally novel histamine $\mathrm{H}_{3}$ receptor antagonists GSK207040 and GSK334429 improve scopolamine-induced memory impairment and capsaicin-induced secondary allodynia in rats. Biochem. Pharmacol. 73(8), 1182-1194 (2007).

50. Passani MB, Giannoni P, Bucherelli C, Baldi E, Blandina P: Histamine in the brain: beyond sleep and memory. Biochem. Pharmacol. 73(8), 1113-1122 (2007).

-51. Lin J-S, Dauvilliers Y, Arnulf I et al.: An inverse agonist of the histamine $\mathrm{H}_{3}$ ) receptor improves wakefulness in narcolepsy: studies in orexin $^{-1-}$ mice and patients. Neurobiol. Dis. 30(1), 74-83 (2008).

52. Esbenshade TA, Browman KE, Bitner RS, Strakhova M, Cowart MD, Brioni JD: The histamine $\mathrm{H}_{3}$ receptor: an attractive target for the treatment of cognitive disorders. Br. J. Pharmacol. 147, 1-16 (2008).

-53. Bakker RA, Lozada AF, van Marle A et al.: Discovery of naturally occurring splice variants of the rat histamine $\mathrm{H}_{3}$ receptor that act as dominant-negative isoforms. Mol. Pharmacol. 69(4), 1194-1206 (2006).

54. Bongers G, Bakker RA, Leurs R: Molecular aspects of the histamine $\mathrm{H}_{3}$ receptor. Biochem. Pharmacol. 73(8), 1195-1204 (2007).

-55. Lovenberg TW, Roland BL, Wilson SJ et al.: Cloning and functional expression of the human histamine $\mathrm{H}_{3}$ receptor. Mol. Pharmacol. 55, 1101-1107 (1999).

56. Clark EA, Hill SJ: Sensitivity of histamine $\mathrm{H}_{3}$ receptor agonist stimulated [35S]GTP- $\gamma[\mathrm{S}]$ binding to pertussis toxin. Eur. J. Pharmacol. 296, 223-225 (1996).

Hill SJ, Straw RM: $\alpha_{2}$-adrenoceptor-mediated inhibition of histamine release from rat cerebral cortical slices. Br. J. Pharmacol. 1213-1219 (1988). 
58. Drutel G, Peitsaro N, Karlstedt K et al.: Identification of rat $\mathrm{H}_{3}$ receptor isoforms with different brain expression and signaling properties. Mol. Pharmacol. 59, 1-8 (2001).

59. Smit M, Leurs R, Alewijnse A et al.: Inverse agonism of histamine $\mathrm{H}_{2}$ antagonists accounts for upregulation of spontaneously active histamine $\mathrm{H}_{2}$ receptors. Proc. Natl Acad. Sci. 93, 6802-6807 (1996).

60. Bakker R, Wieland K, H Timmerman, Leurs R: Constitutive activity of the $\mathrm{H}\left({ }_{1}\right)$ receptor reveals inverse agonism of histamine $\mathrm{H}\left({ }_{1}\right)$ receptor antagonists. Eur. J. Pharmacol. 387, R5-R7 (2000).

61. Morisset S, Rouleau A, Ligneau X et al:: High constitutive activity of native $\mathrm{H}_{3}$ receptors regulates histamine neurons in brain. Nature 408, 860-864 (2000).

- Demonstration of the constitutive activity of the $\mathrm{H}_{3}$ receptor.

62. Wieland K, Bongers G, Yamamoto Y et al:: Constitutive activity of histamine $\mathrm{H}_{3}$ ) receptors stably expressed in SK-N-MC cells: display of agonism and inverse agonism by $\mathrm{H}_{3}$ ) antagonists. J. Pharmacol. Exp. Ther. 299, 908-914 (2001).

63. Rouleau A, Ligneau X, Tardive-Lacombe J et al.: Histamine $\mathrm{H}_{3}$ receptor mediated [35S] GTP $\gamma[s]$ binding: evidence for constitutive activity of the recombinant and native rat and human $\mathrm{H}_{3}$ receptors. Br. J. Pharmacol. 135 , 383-392 (2002).

64. Prast H, Argyriou A, Philippu A: Histaminergic neurons facilitate social memory in rats. Brain Res. 734, 316-318 (1996).

65. Fox GB, Esbenshade TA, Pan JB et al: Pharmacological properties of ABT-239 [4-(2-\{2-[(2R)-2-methylpyrrolidinyl] ethyl\}-benzofuran-5-yl) benzonitrile]: II: neurophysiological characterization and broad preclinical efficacy in cognition and schizophrenia of a potent and selective histamine $\mathrm{H}_{3}$ receptor antagonist. J. Pharmacol. Exp. Ther. 313, 176-190 (2005).

-66. Fox GB, Pan JB, Esbenshade TA et al.: Effects of histamine $\mathrm{H}_{3}$ receptor ligands GT-2331 and ciproxifan in a repeated acquisition avoidance response in the spontaneously hypertensive rat pup. Behav. Brain Res. 131, 151-161 (2002).

67. Fox GB, Pan JB, Radek RJ et al:: Two novel and selective nonimidazole $\mathrm{H}_{3}$ receptor antagonists A-304121 and A-317920: II: in vivo behavioral and neurophysiological characterization. J. Pharmacol. Exp. Ther. 305, 897-908 (2003).
68. Ligneau X, Lin J-S, Vanni-Mercer G et al:: Neurochemical and behavioral effects of ciproxifan, a potent histamine $\mathrm{H}_{3}$-receptor antagonist. J. Pharmacol. Exp. Ther. 287, 658-666 (1998).

69. Meguro K-I, Yanai K, Sakai N et al.: Effects of thioperamide, a histamine $\mathrm{H}_{3}$ antagonist, on the step-through passive avoidance response and histidine decarboxylase activity in senescenceaccelerated mice. Pharmacol. Biochem. Behav. 50(3), 321-325 (1995).

70. Giovannini MG, Bartolini L, Bacciottini L, Greco L, Blandina P: Effects of histamine $\mathrm{H}_{3}$ receptor agonists and antagonists on cognitive performance and scopolamine-induced amnesia. Behav. Brain Res. 104, 147-155 (1999).

71. Giannoni P, Medhurst AD, Passani MB et al:: Regional differential effects of the novel histamine $\mathrm{H}_{3}$ receptor antagonist 6-[(3-cyclobutyl-2,3,4,5-tetrahydro-1H-3benzazepin-7-yl)oxy]- $N$-methyl-3 pyridinecarboxamide hydrochloride (GSK189254) on histamine release in the central nervous system of freely moving rats. J. Pharmacol. Exp. Ther. 332(1), 164-172 (2010).

72. Onodera K, Miyazaki S, Imaizumi M, Stark H, Schunack W: Improvement by FUB 181, a novel histamine $\mathrm{H}_{3}$-receptor antagonist, of learning and memory in the elevated plus-maze test in mice. NaunynSchmiedeberg Arch. Pharmacol. 357(5), 508-513 (1998).

73. Huang YW, Hua WW, Chen Z et al: Effect of the histamine $\mathrm{H}_{3}$-antagonist clobenpropit on spatial memory deficits induced by MK-801 as evaluated by radial maze in Sprague-Dawley rats. Behav. Brain Res. 151, 287-293 (2004).

74. Bongers G, Leurs R, Robertson J, Raber J: Role of $\mathrm{H}_{3}$-receptor-mediated signaling in anxiety and cognition in wild-type and Apoe $e^{-1-}$ mice. Neuropsychopharmacology 29, 441-449 (2004).

-75. Medhurst AD, Roberts JC, Lee J et al.: Characterisation of histamine $\mathrm{H}_{3}$ receptors in Alzheimer's disease brain and amyloid over-expressing TASTPM mice. Br. J. Pharmacol. 157, 130-138 (2009).

76. Quirion R, Wilson A, Rowe W et al:: Facilitation of acetylcholine release and cognitive performance by an $\mathrm{M}_{2}$-muscarinic receptor antagonist in aged memory-impaired rats. J. Neurosci. 15, 1455-1462 (1995).

77. Ennaceur A, Meliani K: Effects of physostigmine and scopolamine on rats' performances in object-recognition and radial-maze tests. Psychopharmacology. 109, 321-330 (1992).
78. Goldman-Rakic PS: Circuitry of primate prefrontal cortex and regulation of behavior by representational memory. In: Handbook of Physiology. Plum F (Ed.). American Physiology Society, MD, USA 373-417 (1987).

79. Khateb A, Fort P, Pegna A, Jones BE, Mühlertaler M: Cholinergic nucleus basalis neurons are excited by histamine in vitro. Neuroscience 69, 495-506 (1995).

80. Mesulam MM, Mufson EJ, Wainer BH, Levey AI: Central cholinergic pathways in the rat: an overview based on an alternative nomenclature (Ch1-Ch6). Neuroscience 10, 1185-1201 (1983).

81. Cecchi M, Passani MB, Bacciottini L, Mannaioni PF, Blandina P: Cortical Acetylcholine release elicited by stimulation of histamine $\mathrm{H}_{1}$ receptors in the nucleus basalis magnocellularis: a dual probe microdialysis study in the freely moving rat. Eur. J. Neurosci. 13, 68-78 (2001).

82. Giannoni P, Passani MB, Nosi D et al.: Heterogeneity of histaminergic neurons in the tuberomammillary nucleus of the rat. Eur. J. Neurosci. 29, 2363-2374 (2009).

- Demonstration that the histaminergic system is organized into distinct circuits modulated by selective mechanisms.

83. Ligneau X, Perrin D, Landais L et al.: BF2.649, a non-imidazole inverse agonist/ antagonist at the human histamine H3-receptor: preclinical pharmacology. J. Pharmacol. Exp. Ther. 320, 365-375 (2007).

84. Medhurst AD, Atkins AR, Beresford IJ et al.: GSK189254, a novel $\mathrm{H}_{3}$ receptor antagonist that binds to histamine $\mathrm{H}_{3}$ receptors in Alzheimer's disease brain and improves cognitive performance in preclinical models. J. Pharmacol. Exp. Ther. 321(3), 1032-1045 (2007).

85. Passani MB, Cangioli I, Baldi E, Bucherelli C, Mannaioni PF, Blandina P: Histamine $\mathrm{H}_{3}$ receptor-mediated impairment of contextual fear conditioning, and in vivo inhibition of cholinergic transmission in the rat basolateral amygdala. Eur. J. Neurosci. 14, 1522-1532 (2001).

- Demonstration that the histaminergic system modulates fear memory consolidation.

86. Cangioli I, Baldi E, Mannaioni PF, Bucherelli C, Blandina P, Passani MB: Activation of histaminergic $\mathrm{H}_{3}$ receptors in the rat basolateral amygdala improves expression of fear memory and enhances acetylcholine release. Eur. J. Neurosci. 16, 521-528 (2002). 
87. Anichtchik OV, Huotari M, Peitsaro N, Haycock JW, Männistö PT, Panula P: Modulation of histamine $\mathrm{H}_{3}$ receptors in the brain of 6-hydroxydopamine-lesioned rats. Eur. J. Neurosci. 12, 3823-3832 (2000).

88. Cenni G, Cangioli I, Yamatodani A et al.: Thioperamide-elicited increase of histamine release from basolateral amygdala of freely moving rats and its therapeutic implications. Inflamm. Res. 53, S53-S54 (2004).

89. Ben-Ari Y, Le Gal La Salle G, Barbin G, Schwartz J-C, Garbarg M: Histamine synthesizing afferents within the amygdaloid complex and bed nucleus of the stria terminalis of the rat. Brain Res. 138, 285-294 (1977).

90. Vizuete ML, Traiffort E, Bouthenet ML et al: : Detailed mapping of the histamine $\mathrm{H}_{2}$ receptor and its gene transcripts in guinea-pig brain. Neuroscience $80,321-343$ (1997).

91. LeDoux JE: Emotion circuits in the brain. Annu. Rev. Neurosci. 23, 155-184 (2000).

92. Sacchetti B, AmbrogiLorenzini C, Baldi E, Tassoni G, Bucherelli C: Auditory thalamus, dorsal hippocampus, basolateral amygdala, and perirhinal cortex role in the consolidation of conditioned freezing to context and to acoustic conditioned stimulus in the rat. J. Neurosci. 19(21), 9570-9578 (1999).

93. Power AE: Muscarinic cholinergic contribution to memory consolidation: with attention to involvement of the basolateral amygdala. Curr. Med. Chem. 11, 987-996 (2004).

94. Giovannini M, Efoudebe M, Passani M et al.: Improvement in fear memory by histamine elicited erk 2 activation in hippocampal CA3 cells. J. Neurosci. 23, 9016-9023 (2003).

95. Crochet S, Sakai K: Effects of microdialysis application of monoamines on the EEG and behavioural states in the cat mesopontine tegmentum. Eur. J. Neurosci. 11, 3738-3752 (1999).

96. Cahill L, McGaugh J: A novel demonstration of enhanced memory associated with emotional arousal. Conscious Cogn. 4, 410-421 (1995).

97. Anaclet C, Parmentier R, Ouk K et al.: Orexin/hypocretin and histamine: distinct roles in the control of wakefulness demonstrated using knock-out mouse models. J. Neurosci. 18(46), 14423-14438 (2009).

-98. Parmentier R, Ohtsu H, Djebarra-Hannas Z, Valtx J-L, Watanabe T, Lin J-S: Anatomical, physiological and pharmacological characteristics of histidine decarboxylase knock-out mice: evidence for the role of brain histamine in behavioral and sleep-wake control. J. Neurosci. 22, 7695-7711 (2002).

99. Nishino S, Fujiki N, Ripley B et al.: Decreased brain histamine content in hypocretin/orexin receptor-2 mutated narcoleptic dogs. Neurosci. Lett. 313, 125-128 (2001).

100. Sakai K, Mansari ME, Lin J, Zhang J, Mercier GV: The posterior hypothalamus in the regulation of wakefulness and paradoxical sleep. In: The Diencephalon and Sleep. Mancia M (Ed.). Raven Press, NY, USA 171-198 (1990).

101. Lin JS: Brain structures and mechanisms involved in the control of cortical activation and wakefulness, with emphasis on the posterior hypothalamus and histaminergic neurons. Sleep Med. Rev. 4, 471-503 (2000).

102. Lin J, Sakai K, Jouvet M: Hypothalamopreoptic histaminergic projections in sleep-wake control in the cat. Eur. J. Neurosci. 6, 618-625 (1994).

103. Lin JS, Hou Y, Sakai K, Jouvet M: Histaminergic descending inputs to the mesopontine tegmentum and their role in the control of cortical activation and wakefulness in the cat. J. Neurosci. 16, 1523-1537 (1996).

- Demonstrates that histamine produces a waking effect.

104. Le S, Gruner JA, Mathiasen JR, Marino MJ, Schaffhauser H: Correlation between ex vivo receptor occupancy and wake-promoting activity of selective $\mathrm{H}_{3}$ receptor antagonists. J. Pharmacol. Exp. Ther. 325(3), 902-909 (2008).

105. Guo RX, Anaclet C, Roberts JC et al.: Differential effects of acute and repeat dosing with the $\mathrm{H}_{3}$ antagonist GSK189254 on the sleep-wake cycle and narcoleptic episodes in $\mathrm{Ox}^{-1-}$ mice. Br. J. Pharmacol. 157(1), 104-117 (2009).

106. Lin JS, Dauvilliers Y, Arnulf I et al.: An inverse agonist of the histamine $\mathrm{H}_{3}$ receptor improves wakefulness in narcolepsy: studies in orexin $^{-1}$ mice and patients. Neurobiol. Dis. 30(1), 74-83 (2008).

107. Arnulf I: Results of clinical trials of tiprolisant in narcolepsy and Parkinson's disease. Eur. Neuropsychopharmacol. 19, S204 (2009).

108. Sander K, Kottke T, Stark H: Histamine $\mathrm{H}_{3}$ receptor antagonists go to clinics. Biol. Pharm. Bull. 31, 2163-2181 (2008).

109. Lin JS: Brain structures and mechanisms involved in the control of cortical activation and wakefulness, with emphasis on the posterior hypothalamus and histaminergic neurons. Sleep Med. Rev. 4(5), 471-503 (2000).

110. Cannon KE, Hough LB: Inhibition of chemical and low-intensity mechanical nociception by activation of histamine $\mathrm{H}_{3}$ receptors. J. Pain 6(3), 193-200 (2005).

- Study showing $\mathrm{H}_{3}$-receptor involvement in nociception.

111. Lozada A, Munyao N, Sallmen T et al: Postischemic regulation of central histamine receptors. Neuroscience 136(1), 371-379 (2005).

112. Lintunen M, Sallmen T, Karlstedt K, Panula $P$ : Transient changes in the limbic histaminergic system after systemic kainic acid-induced seizures. Neurobiol. Dis. 20 (1), 155-169 (2005).

113. Kukko-Lukjanov TK, Soini S, Taira T, Michelsen KA, Panula P, Holopainen IE: Histaminergic neurons protect the developing hippocampus from kainic acid-induced neuronal damage in an organotypic coculture system. J. Neurosci. 26(4), 1088-1097 (2006).

114. Emamian ES, Hall D, Birnbaum MJ, Karayiorgou M, Gogos JA: Convergent evidence for impaired AKT1-GSK3 $\beta$ signaling in schizophrenia. Nat. Genet. 36(2), 131-137 (2004).

115. Kaytor MD, Orr HT: The GSK3 $\beta$ signaling cascade and neurodegenerative disease. Curr. Opin. Neurobiol. 12(3), 275-278 (2002).

116. Hooper C, Killick R, Lovestone S: The GSK3 hypothesis of Alzheimer's disease. J. Neurochem. 104(6), 1433-1439 (2008).

117. Mason ST, Fibiger HC: Regional topography within noradrenergic locus coeruleus as revealed by retrograde transport of horseradish peroxidase. J. Comp. Neurol. 187(4), 703-724 (1979).

118. Jacobs BL, Azmitia EC: Structure and function of the brain serotonin system. Physiol. Rev. 72(1), 165-229 (1992).

119. Kohler C, Swanson L, Haglund L, Wu J: The cytoarchitecture, histochemistry and projections of the tuberomammillary nucleus in the rat. Neuroscience 16, 85-110 (1985).

120. Yang Q Z, Hatton GI: Electrophysiology of excitatory and inhibitory afferents to rat histaminergic tuberomammillary nucleus neurons from hypothalamic and forebrain sites. Brain Res. 773, 162-172 (1997).

121. Stevens DR, Kuramasu A, Haas HL: GABA B-receptor-mediated control of GABAergic inhibition in rat histaminergic neurons in vitro. Eur. J. Neurosci. 11, 1148-1154 (1999). 
122. Cenni G, Blandina P, Mackie K et al.: Differential effect of cannabinoid agonists and endocannabinoids on histamine release from distinct regions of the rat brain. Eur. J. Neurosci. 24, 1633-1644 (2006).

123. Sergeeva OA, Eriksson KS, Sharonova IN, Vorobjev VS, Haas HL: GABA $\left(_{A}\right)$ receptor heterogeneity in histaminergic neurons. Eur. J. Neurosci. 16(8), 1472-1482 (2002).
124. Sergeeva OA, Andreeva N, Garret M, Scherer A, Haas HL: Pharmacological properties of $\mathrm{GABA}_{\mathrm{A}}$ receptors in rat hypothalamic neurons expressing the E-subunit. J. Neurosci. 25(1), 88-95 (2005).

125. Huang Z-L, Sato Y, Mochizuki T et al.: Prostaglandin E2 activates the histaminergic system via the EP4 receptor to induce wakefulness in rats. J. Neurosci. 23(14), 5975-5983 (2003).
126. Huang Z-L, Qu W-M, Li W-D et al.: Arousal effect of orexin A depends on activation of the histaminergic system. Proc. Natl Acad. Sci. 98, 9965-9970 (2001).

- Demonstrated that histamine neurons are involved in sleep regulation by orexin neurons. 